\title{
Information analysis of online collaborative company review
}

\author{
Timothy Rey Laheba \\ Faculty of Technology Industry, Universitas Atma Jaya Yogyakarta \\ Timothy.rey@uajy.ac.id \\ The Jin Ai \\ Faculty of Technology Industry, Universitas Atma Jaya Yogyakarta \\ The.jinai@uajy.ac.id
}

\begin{abstract}
Received: May, 2021; Accepted: July, 2021; Published: September, 2021
DOI: https://doi.org/10.24123/jmb.v20i2
\end{abstract}

\begin{abstract}
In this era of industry 4.0, the role of technology is getting bigger and broader in the industry. This technology has changed some old habits and paradigms in the relationship between companies and job seekers. One of the current changes is that job seekers can find information related to a company through an online collaborative company review that can be found easily on the employment website. This study aims to determine what information job seekers consider essential from an online collaborative review of a company. Data from the 203 millennial generations in Indonesia were collected. The study results found that the most sought-after variable from an online collaborative company review was Basic salary exposition, followed by Job description. The following variable is Work-life balance or working condition, followed by the Company profile variable, Benefits and incentives, Positive things about a company, and negative things about a company.
\end{abstract}

Keywords: information, online collaborative company review, employment website.

\begin{abstract}
Abstrak
Pada era industry 4.0 peran teknologi semakin besar dan masif dalam setiap industri. Pemanfaatan teknologi ini telah merubah beberapa kebiasaan dan paradigma lama dalam hubungan antara perusahaan dan para pencari kerja. Salah satu perubahan yang terjadi saat ini adalah para pencari kerja dapat mencari informasi terkait sebuah perusahaan melalui online collaborative company review yang dapat ditemui dengan mudah pada banyak employment website. Penelitian ini bertujuan untuk menemukan informasi apa yang dianggap penting oleh para pencari kerja dari online collaborative review sebuah perusahaan. Data dari 203 generasi milenial Indonesia dikumpulkan dalam penelitian ini. Hasil
\end{abstract}


penelitian menemukan bahwa variabel yang paling dicari dari sebuah online collaborative company review berturut turut adalah Gaji pokok, diikuti dengan deskripsi pekerjaan, Work-life balance atau Kondisi dan Beban Kerja, Profil perusahaan, Tunjangan dan Bonus, Hal positif tentang sebuah perusahaan dan terakhir adalah $\mathrm{Hal}$ negatif tentang sebuah perusahaan.

Kata Kunci: informasi, online collaborative company review, employment website.

\section{INTRODUCTION}

We have arrived at the Era of Industrial 4.0. Industrial revolution 4.0 is possible because of the massive use of technology in an industry (Gajdzik et al., 2020; Thun et al., 2019). At first, the technology's use only occurred in an industry's production process using machines and automation processes. However, over time, the current use of technology has changed so many old paradigms in most industry departments. One of the significant changes that have occurred due to this technology's development is the relationship between a company and job seekers.

Technological advancement is the main reason for information disclosure today. Technological developments coupled with the extensive use of the internet have allowed people to access previously impossible information (Molino et al., 2020). One group of people that have benefited from this phenomenon are job seekers. In the past, job seekers would find it very difficult to find information about working conditions in a company before they entered and worked for a particular company. However, the current openness of information allows job seekers to find information that can help them choose the most appropriate company.

Online reviews can become a great source of information for job seekers to know where they will work. A job worker needs precise data and information to decide where they should work (Reamer, 2016). One source of information currently sought after and utilized by many job seekers is company reviews available on online platforms. This online company review can be found on multiple news websites, job websites, and social media. In addition, this online company review contains some information that can be used as a reference by job seekers, such as working conditions, salary, and overall rating for a company. Easiness of access has become the main reason for the rise of online company reviews by job seekers. 


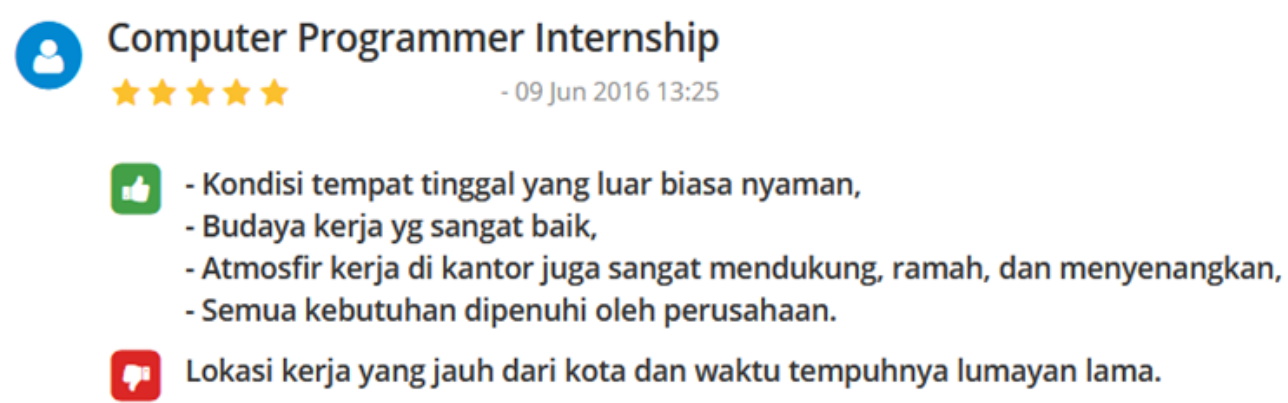

$\begin{array}{ll}\text { Gaji \& Tunjangan } & \text { Jenjang Karir } \\ \text { Helpful } & \text { Nilai \& Budaya } \\ \text { Hork/Life Balance } & \end{array}$

Figure 1. Example of Online Collaborative Review on Employment Website Source: Qerja.com (2020)

Online collaborative company reviews will have better information compared to reviews that only one person provides. Two things that are the main reasons the information obtained from online reviews can be trusted are the reviewer's credibility and objectivity (Moriuchi, 2018). This phenomenon is why online collaborative company reviews are more trusted than other online reviews available on the internet. Many employment websites such as Jobstreet, Qerja, and Glassdoor provide this online collaborative company review. The employment website offers a platform where former and current employees can provide reviews and helpful information for job seekers. Diverse sources from various company positions make online collaborative company reviews have miscellaneous information and help job seekers. An example of an online collaborative company review can be seen in Figure 1.

Nowadays, many employment websites provide online collaborative reviews and highlight them as the main features to attract job seekers. However, the employment website is still looking for the most appropriate formula for presenting collaborative online company reviews to attract job seekers. This research will help find what information is considered the most essential for jobseekers when looking for online collaborative company reviews. The employment website will be supported to present online collaborative company reviews to job seekers by understanding this. This research is also expected to help job seekers find helpful information to determine the most appropriate company for their career journey.

Several variables can affect the job satisfaction of workers in a company. Good human resource management in a company will positively correlate with worker satisfaction (Cherif, 2020). In his research on 
employees who work in offshore areas, it is found that working in offshore areas gives employees lower job satisfaction compared to workers that work in the office. The intensity of work in the offshore area negatively impacts job satisfaction among workers (Budría \& Baleix, 2020). Within their research on 120 self-financing university professors, there are positive relationships between the ethical climate of certain workplaces and job satisfaction (Kamalaselvi \& Mahalakshmi, 2020). In their research in polish transportation company, it is found that one of the main variables determining workers' job satisfaction in a company is access to information to help workers do their job better. A company should always pay attention to what factor can keep their employee satisfied when doing their job to get the best performance from their employee (Jędrzejczak-Gas \& Wyrwa, 2020).

Excellent job information will help job seekers choose the best company that fits their skills and personality. A job seeker will try to find information about their future manager from social media to understand their prospective supervisor before starting a job. For example, an alcohol abused relative posted on social media by a manager will negatively impact the intention to work for that manager from a future job seeker (Ballweg et al., 2019). Information quality will positively influence the benefits and desire of job seekers to use a website of job information, and a good dimension of information quality of an employment website will increase the trust of the job seeker towards the website (Priyadarshini et al., 2017). For fresh graduate that their behaviour will represent the future workforce. Social media, in this case, is Linkedin, which can be a source of information used by job seekers to find information about a company (Sajjad Hosain \& Liu, 2020). In the sales department it is considered one of the hardest positions due to its responsibilities and pressures. By communicating new things in sales, a company will increase prospective employees' desires to work with their company (Kim \& Talbott, 2018).

Online reviews are a reliable source of information and are widely used by a lot of people today. A significant relationship was found between reading and using online reviews and users' desire to use a website (Rrustemi \& Jashari, 2018). An online review that is manipulated will have a negative impact on the website that displays the online review (Moriuchi, 2018). On the other hand, reviews that are not too long and provide positive information will positively impact user reviews (Ghasemaghaei et al., 2018). An average review obtained and found by customers on a website is one of the leading choices in finding information (Lee et al., 2021).

The quality of information is one of the main factors that can make people trust online reviews. A study found that good self-efficacy in obtaining information will affect satisfaction in the decision-making process (Zha et al., 2013). When you have too little information, adding images to online reviews can increase trustworthiness and provide information that is not found in worded reviews (Zinko et al., 2020). Diverse and varied 
information and types of products can affect the perception of online review users' quality of information (Zhu et al., 2020).

Even though several kinds of research try to find and understand the type and impact of the online review on how it affects jobseeker to trust the information provided in some online platform, until today, no research has been conducted to find what information is considered the most important by the job seeker that used online collaborative company reviewed that viewed as a more objective review due to its review come from various people.

There is still no research that specifically tries to determine what kind of information is considered essential and valuable by job seekers in Indonesia in online collaborative company review by understanding some previously done research. Therefore, the hypothesis developed in this study is:

$H_{0}$ : There is no difference between the importance ranking of each variable of the information searched by users of the employment website.

$H_{1}$ : There is a difference between the importance ranking of each variable of the information searched by users of the employment website.

\section{RESEARCH METHODS \\ Population and Sample}

This study's population is all job seekers in Indonesia who plan to use a collaborative online company review as a tool to obtain information about a company and jobs within the company. In this study, the sample used was Indonesia's millennial generation. The reason for choosing this group of people as the sample is that this generation is a generation familiar with technology, especially online reviews, within their everyday lives. Many of them can also be classified as first-time job seekers who are still exploring a lot to find the most appropriate career. The research methodology flow chart is presented in figure 2 .

\section{Friedman's Two-Way Anova with Ranks}

The nonparametric version of the parametric Two-way Analysis of Variance (ANOVA) by Ranks Test is Friedman's Two-way Analysis of Variance (ANOVA) by Ranks Test (MacFarland et al., 2016). For comparisons of several groups of different variables, both the parametric methods of Two Way ANOVA and the nonparametric Friedman Test can be used to see any statistically relevant variations. With ranked data, the Friedman Test is used as a nonparametric test, particularly when:

1. The Data cannot be classified as interval data, and the method will be beneficial when the data collected is ordinal measurement type of data.

2. There are serious concerns about extreme deviation from normal distribution For data collected.

3. There is a considerable difference in the number of subjects for each breakout group.

Friedman's two-way ANOVA with ranks was chosen for this research because the respondents will be asked to rank the most important 
information they look to find about information provided in online collaborative company reviews. Thus, this method will organize information on which information is considered the most important by the respondents.

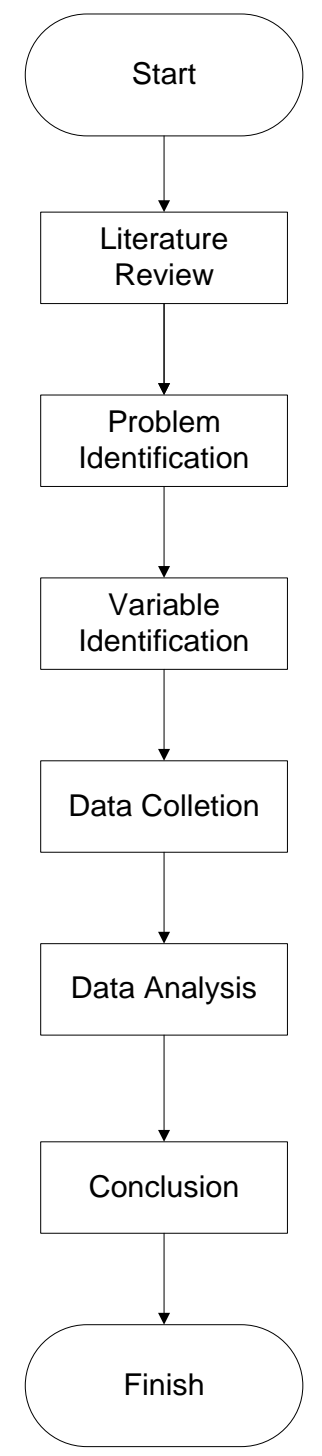

Figure 2. Research Methodology Diagram

\section{Variable}

Variable of information in online collaborative company review used in this research include:

1. Basic salary

This variable will relate to information related to the basic salary of a company in an online collaborative company review.

2. Benefits and Incentives

This variable will relate to information about various benefits such as holiday allowances and services received by an employee in a company, such as health insurance facilities and others. 
3. Work-Life Balance and Company conditions

This variable will discuss the working conditions described in a company's online collaborative review. It will help job seekers understand the company's culture and views on work-life balance, which is increasingly becoming one of the main factors in choosing a workplace for the millennial generation.

4. Job description

From this variable, job seekers will find a job description and responsibilities for a particular position in a company.

5. Company Profile / Company Business

This variable will explain job seekers who use a collaborative online review about a company's profile, including the business profile, number of employees, and other things related to the company.

6. Positive things about a company

This variable will consist of positive things that are felt by reviewers while working in a company.

7. Negative things about a company

This variable will consist of negative things that are felt by reviewers while working in a company.

\section{Research Instrument}

The data in this research is collected using Google forms. The questionnaire within this research is distributed using a google form to provide broader and faster access in times of the COVID-19 pandemic. All the data collected in this research will be analyzed with the help of IBM SPSS software. The data were collected in March 2021 for the duration of three weeks.

\section{RESULT AND DISCUSSION}

Data from 203 millennial generations within the age range of $17-23$ years old were collected and analyzed for this study. This research is a cross-sectional study. Validity and reliability testing were conducted for the questionnaire, and all the questions are valid. The hypotheses testing summary can be seen in Table 1 . From Table 1 can be seen that the significance is less than 0,05 , which means that $\mathrm{H}_{0}$ from this study can be rejected. There is a difference in the ranking distributions of Basic Salary, Benefits and Incentive, Work-Life Balance or Working Condition, Job Description, Company Profile, Positive Thing about a Company, and Negative Things About a Company. After this is confirmed, the next step is to find the difference in these variables' ranking distribution. 
Table 1. Hypothesis Testing Summary

Null Hypotesis

Test

Sig. Decision

The Distributions of Basic Salary, Benefits and Incentive, Work-Life Balance or Working Condition, Job Description, Company Profile, Positive Thing about a Company, and Negative Things

Related-Samples Friedman's TwoWay Analysis of Variance by Ranks
$0,000 \quad \begin{array}{ll}\text { Reject null } \\ \text { hypotheses }\end{array}$

About a Company are The same.

The average ranking value of the information sought by the millennial generation using online collaborative company review can be seen in Figure 3.

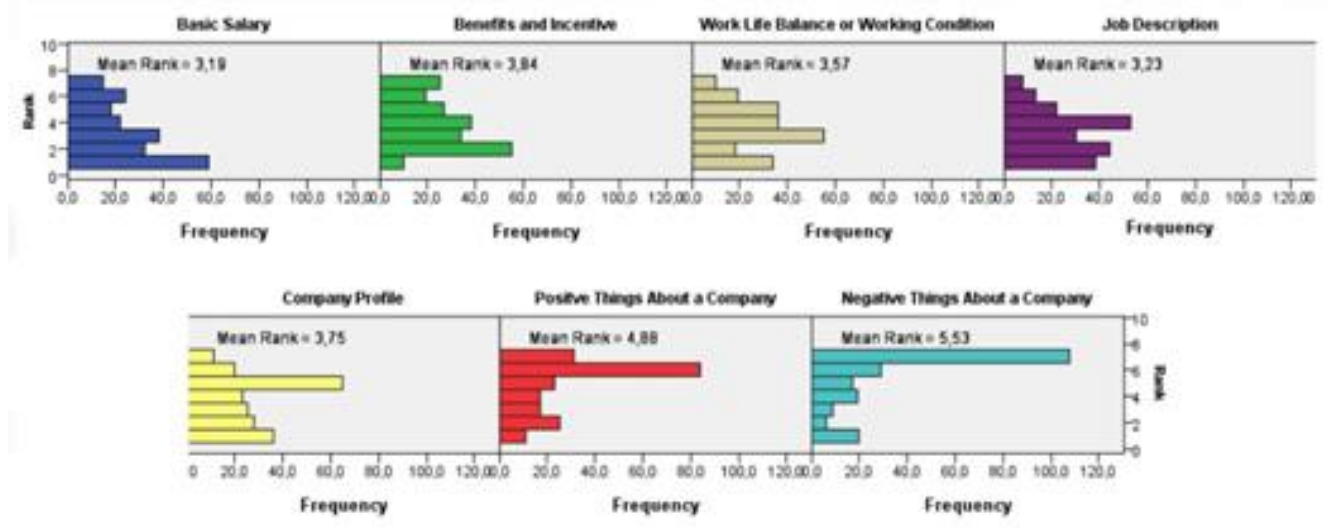

Figure 3. Average Ranking Value for Information Variable on Online Collaborative Company Review

In Figure 3, we can see that the average ranking value for the Basic salary variable is 3,19 . The average ranking value for the Benefit and Incentive variable is 3.84. The average ranking value for the Work-Life balance or Working condition variable is 3.57 . The average ranking value for the Job description variable is 3.23 . The average ranking value for the company profile variable is 3.75 . The average ranking value for the positive things about a company variable is 4.88 . The average ranking value for the negative things about a company variable is 5.53 . We will examine and conclude which variable of information respondents considered the most important in using online collaborative company reviews from this ranking value.

\section{CONCLUSION}

This study aims to find the best concept in providing information in collaborative online company review. From previous research, it was already determined that nowadays, due to the openness of information, many job seekers use online review available on the internet to find what 
jobs or company is the best fit for their skill and knowledge. It is also known that exposing and sharing relevant information about a company will give many job seekers helped and prepared better for their future company. With many employment websites offering online collaborative company reviews as one of the main features to attract users, it is crucial to understand what kind of information the user needs to create the best visualization of information needed by the job seeker.

However, not all collaborative online company review variables are considered equally important by the job seeker. This study found that the variables from online collaborative company review on an employment website have different importance. This study found that the variables that are considered the most important for Job seekers are Basic salary exposition, followed by Job description. The following variable is Work-life balance or working condition, followed by the Company profile variable, Benefits and incentives, Positive things about a company, and negative things about a company.

This research tries to find what variables are considered to be most important by job seekers. This study can be developed in further analysis by understanding which attributes from a collaborative online company review make the review trusted by the job seekers.

\section{ACKNOWLEDGEMENT}

A big thank you to LPPM Universitas Atma Jaya Yogyakarta and the Department of Industrial Engineering to support this research.

\section{REFERENCES}

Ballweg, C. A., Ross, W. H., Secchi, D., \& Uting, C. (2019). The influence of managers' social networking information on job applicants. Evidence-Based HRM, 7(2). https://doi.org/10.1108/EBHRM-03-2018-0023

Budría, S., \& Baleix, J. M. (2020). Offshoring, job satisfaction and job insecurity. Economics, 14. https://doi.org/10.5018/economics-ejournal.ja.2020-23

Cherif, F. (2020). The role of human resource management practices and employee job satisfaction in predicting organizational commitment in Saudi Arabian banking sector. International Journal of Sociology and Social Policy, 40(7-8). https://doi.org/10.1108/IJSSP-10-2019-0216

Gajdzik, B. zena, Grabowska, S., Saniuk, S., \& Wieczorek, T. (2020). Sustainable development and industry 4.0: A bibliometric analysis identifying key scientific problems of the sustainable industry 4.0. Energies, 13(6). https://doi.org/10.3390/en13164254

Ghasemaghaei, M., Eslami, S. P., Deal, K., \& Hassanein, K. (2018). Reviews' length and sentiment as correlates of online reviews' ratings. Internet Research, 28(3). https://doi.org/10.1108/IntR-12-2016-0394

Jędrzejczak-Gas, J., \& Wyrwa, J. (2020). Determinants of job satisfaction in a transport company: a Polish case study. Equilibrium, 15(3). https://doi.org/10.24136/eq.2020.025

Kamalaselvi, G. \& Mahalakshmi, G. (2020). 42 . IMPACT OF WORKPLACE ETHICS ON JOB SATISFACTION AND JOB COMMITMENT OF SELF FINANCING COLLEGE PROFESSORS - A STUDY WITH. 4(1), 252-260. 
Kim, Y., \& Talbott, J. S. (2018). Marketing social selling jobs: a re-labelling strategy. Marketing Intelligence and Planning, 36(1). https://doi.org/10.1108/MIP-03-2017-0056

Lee, S., Lee, S., \& Baek, H. (2021). Does the dispersion of online review ratings affect review helpfulness? Computers in Human Behavior, 117. https://doi.org/10.1016/j.chb.2020.106670

MacFarland, T. W., Yates, J. M., MacFarland, T. W., \& Yates, J. M. (2016). Friedman Twoway Analysis of Variance (ANOVA) by Ranks. In Introduction to Nonparametric Statistics for the Biological Sciences Using $R$. https://doi.org/10.1007/978-3-319-30634-6_7

Molino, M., Cortese, C. G., \& Ghislieri, C. (2020). The promotion of technology acceptance and work engagement in industry 4.0: From personal resources to information and training. International Journal of Environmental Research and Public Health, 17(7). https://doi.org/10.3390/ijerph17072438

Moriuchi, E. (2018). IS THAT REALLY AN HONEST ONLINE REVIEW? THE EFFECTIVENESS OF DISCLAIMERS IN ONLINE REVIEWS. Journal of Marketing Theory and Practice. https://doi.org/10.1080/10696679.2018.1451257

Priyadarshini, C., Sreejesh, S., \& Anusree, M. R. (2017). Effect of information quality of employment website on attitude toward the website: A moderated mediation study. International Journal of Manpower, 38(5). https://doi.org/10.1108/lJM-12-2015-0235

Reamer, A. (2016). Better jobs information benefits everyone. Issues in Science and Technology, 33(1).

Rrustemi, V., \& Jashari, F. (2018). Impact of Online Reviews in Online Booking Case Study Capital City of Kosovo. EuroEconomica.

Sajjad Hosain, M., \& Liu, P. (2020). Linked in for searching better job opportunity: Passive jobseekers' perceived experience. Qualitative Report, 25(10).

Thun, S., Kamsvåg, P. F., Kløve, B., Seim, E. A., \& Torvatn, H. Y. (2019). Industry 4.0: Whose revolution? The digitalization of manufacturing work processes. Nordic Journal of Working Life Studies, 9(4). https://doi.org/10.18291/njwls.v9i4.117777

Zha, X., Li, J., \& Yan, Y. (2013). Information self-efficacy and information channels: Decision quality and online shopping satisfaction. Online Information Review, 37(6). https://doi.org/10.1108/OIR-09-2012-0156

Zhu, L., Li, H., He, W., \& Hong, C. (2020). What influences online reviews' perceived information quality? The Electronic Library, 38(2). https://doi.org/10.1108/el-09-2019-0208

Zinko, R., Stolk, P., Furner, Z., \& Almond, B. (2020). A picture is worth a thousand words: how images influence information quality and information load in online reviews. Electronic Markets, 30(4). https://doi.org/10.1007/s12525-019-00345-y 